\title{
Placed Upon the Landscape, Casting Shadows: Jewish Canadian Monuments and Other Forms of Memory
}




\begin{abstract}
This essay explores monuments, including the National Holocaust Monument in Ottawa, and gravestones in Jewish cemeteries in Montreal and Vancouver. Alongside these sites it considers how Canadian Jewish literature presents possibilities for Jewish history and language to mark the Canadian landscape though a consideration of Leonard Cohen and Eli Mandel. A discussion of Canadian monuments is relevant in light of recent demonstrations focused on removing statues and monuments from parks and government buildings. The essay contrasts community-inspired projects like Vancouver's Holocaust memorial with Ottawa's "National" monument, whose unveiling prompted a discussion about appropriate ways to represent history.
\end{abstract}

\title{
Résumé
}

Cet essai explore les monuments, y compris le monument national de l'Holocauste à Ottawa, et les pierres tombales des cimetières juifs de Montréal et de Vancouver. Parallèlement à ces sites, il examine comment la littérature juive canadienne, notamment les écrits de Leonard Cohen et Eli Mandel, offre des opportunités pour l'histoire et la langue juives de marquer le paysage canadien. Une discussion sur les monuments canadiens est pertinente à la lumière des récentes manifestations visant à retirer les statues et les monuments des parcs et des édifices gouvernementaux. L'essai met en contraste des projets d'inspiration communautaire comme le mémorial de l'Holocauste de Vancouver et le monument «national d'Ottawa, dont le dévoilement a suscité une discussion sur les moyens appropriés de représenter l'histoire.

\section{Placed Upon the Landscape, Casting Shadows: Jewish Canadian Monuments and Other Forms of Memory}

There it was, lying on the landscape - the neatly manicured and mapped downtown Montreal Place du Canada - the first Prime Minister's head. It lay at some distance from the body it had been attached to since its casting in I895, when the country was young. The protesters who felled it had achieved their goal of reducing its lofty position of solemn oversight to that of discarded leftovers. It was Leon Trotsky-possibly a motivating figure for some of the protesters - who expressed a desire to see twentieth-century political systems and their representatives dumped into the "dustbin of history," and John A. Macdonald's status was under some threat, at least of being repositioned in the country's historical narrative. Macdonald's statue, casting shadows for more than a century, was likely proposed by a city councillor or a philanthropist from Montreal's Golden Square Mile, and it reflected, for 125 years, a mainstream view of how Canadian history and ideals should be marked on the landscape. ${ }^{2}$ Place du Canada is at the heart of urban Montreal, surrounded by constantly chang- 
ing streetscapes. Along with Macdonald it contains cannons gifted by Queen Victoria, walkways, quadrangles, and plantings made possible by the uprooting of a Catholic cemetery, whose interred were removed to designated sections of a cemetery on Mount Royal. A nearby Jewish cemetery was also removed to make way for the construction of a church. One might try (and fail) to find at Place du Canada what historian Simon Schama calls "the ghostly outline of an old landscape beneath the superficial covering of the contemporary."3 The narrative of Jewish life and death, once evident in the heart of urban Montreal, was moved to the city's west side before Macdonald ascended his plinth. Monuments; memorials; historical plaques; these are tools for adapting a natural or developing urban surround to culture. Knocking them down, defacing them, carrying them off, are among the ways to bring about a cultural narrative's reconsideration.

How unlikely and rare it is in Canada for such markings, monuments, and memorials on the landscape to include Jewish language and narrative, or to represent, as this collection of essays means to explore, how Jews have "carved their identity into the Canadian landscape-physically and literally, or otherwise." One recent exception to this rule is the National Holocaust Monument, completed in the fall of 2017 on Ottawa's LeBreton Flats near the banks of the Ottawa River. Initiated under Conservative Prime Minister Stephen Harper, its funding came from the federal government, Jewish communal philanthropy, as well as corporate and private donations. In this way, it is the outcome of collaboration between different communities and constituencies. A careful look at its development reveals how the monument is linked to both a Canadian Jewish impetus to commemorate the Holocaust as well as to broader national goals rooted in mainstream culture, which this essay will explore.

The monument's location, west of Parliament Hill at the confluence of Sir John A. Macdonald Parkway and Booth Street, places it within the larger complement of National Capital sites of meaning and memory. Its lead designer, architect Daniel Libeskind, is a Polish-born American Jew whose firm's chief operating officer is his Canadian-born wife Nina Libeskind. The monument's angularity, its brute concrete components, meant, one would expect, to evoke brutal history, are of a piece with Libeskind's more fêted constructions, including his Jewish Museum in Berlin.

The Holocaust monument's markings-the written and illustrative messages it presents to viewers at its outdoor site-became a bureaucratic fiasco in the summer of 2017, just prior to its opening to the public, when it was reported that its introductory plaque, which introduces the rest of its written and illustrative texts, mentioned millions of victims of German genocidal war without using the word Jew. As the issue played out in the press, an email about the 2.4 by 1.5 metre plaque was sent by the office of then Minister of Canadian Heritage Mélanie Joly: "What was the approval process for this text? Did it go by committee?"s Whatever the answer to 
these questions, the snafu the plaque created reveals at least one thing: it made use of language that was strange to Jews committed to Holocaust commemoration. Even with the involvement of Jewish design professionals and bureaucrats, the plaque's message was obscured by a bureaucratic, neutralizing, national code for official federal markings on the landscape.

In light of what wasn't, at first, said on LeBreton Flats, where should we look to find prominent Jewish markings on the Canadian landscape? In the early decades of the twentieth century, one found them on shop window advertisements aimed at Yiddish-speaking clientele. Spadina Avenue, Kensington Market, the streets surrounding the Main in Montreal, retail avenues in Winnipeg, presented a Yiddish language panoply to the eye of any passerby, who might or might not know the difference between "Do davent men yedn tog" or "Frish yedn tog." Sign painters for such markings, and those who read them with ease, are buried in cemeteries in this country's cities, towns and outlying prairies. Those cemeteries, like the early nineteenth-century burial ground removed from the plaza that became John A. Macdonald's lookout in Place du Canada, are worthy of our consideration as sites of Jewish markings on the landscape.

Like the statue of Macdonald, Jewish cemeteries are mute markers that sometimes withstand vandalism. They throw shadows this way and that, as a statue does, and they offer a varying array of inscriptions. Most markings on Jewish gravestones are in Hebrew, a language that non-Jewish Canadians do not read, so these remain coded inscriptions. But one can begin to decipher something on most Jewish gravestones. Like the Place du Canada Macdonald plinth, they include a name, most often carved in block letters in granite, which is routinely conveyed in English. Jewish gravestones alternate between languages, as they provide a Hebrew text translated to some degree into English (or into the language appropriate to the person interred).

Jewish cemeteries often include Holocaust memorials and monuments whose language provides interesting contrast with the rejected plaque at Ottawa's National Holocaust Monument. It read, in part: "The National Holocaust Monument commemorates the millions of men, women and children murdered during the Holocaust and honours the survivors who persevered and were able to make their way to Canada ..." In contrast, a substantial memorial and monument was unveiled in Vancouver's Schara Tzedeck cemetery on April 26, Yom Hashoah, in 1987. ${ }^{8}$ Its organization was motivated by survivors who gathered names of Vancouverites' family members who were murdered by the Germans during the war. The outcome, an elaborate and impressive commemorative monument, is trilingual. The Hebrew word for memory, zachor, dominates entry posts, while a Hebrew dedication to those "brutally murdered during the Nazi Holocaust" is prominent on the monument's central column. ${ }^{9}$ A dedication in Yiddish rings a grouping of English-language names for German death camps. In a separate and extensive set of tablets surround- 
ing the monument are etched the many names of the wartime murdered whose descendants lived in Vancouver in the 1980 s. $^{\text {IO }}$ With this western Canadian example, the tenor of what might be called a homegrown Holocaust memorial, its contents, language, and tone, come into focus.

The most commonly viewed Jewish grave markers in Canada must be those of the Cohen family in Montreal's Shaar Hashomayim cemetery, where Leonard Cohen was buried on November Io, 2016." Like the Vancouver Holocaust monument, with its cultural history written into its multilingual presentation, the Cohen gravestones tell their own particular Canadian Jewish narrative.

Traditionally, immediately after burial, a Jewish grave is nondescript-the word's dictionary meaning, "not easily described" is apropos-since a gravestone is not put up for twelve months. ${ }^{12}$ What appears on any given stone reveals a myriad of cultural tendencies and trends, which reflect each family's cultural and religious outlook. Leonard Cohen's grave site on Montreal's Mount Royal is a rich text, ripe for deconstruction (not just veneration, which is the response it receives from those who leave stones, candles, and flowers at it). The Cohen family monument is outsized and impressive, squared off and grey, with one English word carved on it in block letters: "COHEN." This is, in fact, a longstanding European Jewish approach to family crypts; a notable example being the gigantic family crypt that belonged to the leading prewar Lodz manufacturing family, which is inscribed in large, stylized letters: "POZNANSKI."

Leonard Cohen's individual stone, at remove from the family monument, has two parts. Jewish gravestones take many shapes. Some are upright, tall, and broad, while others are modest, rectangular, and flat, raised some eight inches off the ground. Cohen's grave is marked by one of each of these. The upright, more substantial marker is at the grave's head, with the lesser, flat-placed stone at the foot of the grave. Cohen's dominant upright marker resembles the family's central monument in its soft grey stone. It bears the name of the deceased in English: "LEONARD COHEN," followed by Cohen's dates, "I934-2016." Additionally, above Cohen's name is the logotwo hearts placed to create a modified Star of David - which was used on Cohen's later records and book covers. The smaller marker at the grave's foot is an example of the bilingual, religiously inflected stones that North American Jews have placed in cemeteries for at least a century. Information - including name and date of death-is in Hebrew and English, to which the stone cutter has added traditional Hebrew abbreviations. These are the letters pe and nun, signifying the Hebrew words for "here lies"; and five Hebrew letters separated by apostrophes, which denote a line from the Book of Samuel, which declares, "May his soul be bound up in the bond of eternal life." ${ }^{\prime 3}$ Each marker at Cohen's grave has a distinct purpose and its own audience. 
The upright stone with the logo that appeared on Cohen's work and promotional materials speaks to his fans, while the flat-placed stone is only partly legible to those without Hebrew. Further, the flat stone is fully readable only by Jews who know the meaning of the traditional Hebrew abbreviations. Cohen's genius throughout his career included an ability to open his work, through its themes and imagery, to Jewish and non-Jewish audiences, although his mid-career religious poetry in The Book of Mercy must seem coded to the non-Jewish reader. His grave is a telling addition to his own writerly rendering of Jewish life on the Canadian landscape.

Cohen's compatriot in Canadian letters, the much lesser-known but excellent poet Eli Mandel, provides an interesting counter-text to Cohen's grave site in his collection Out of Place. Published in 1977 in an unusually large page format, Out of Place juxtaposes short, sometimes fragmentary poems with photographs taken by Ann Mandel, the poet's wife at the time. The photos depict the poems' subject-the southern Saskatchewan communities of Hirsch and Estevan where Mandel's family settled and thrived in the early decades of the twentieth century. Included among the photos are full-page images of gravestones in the Hirsch cemetery. In his recollections of Jewish farm and town life, one of Mandel's focal points is these markers, near to where his grandfather, the community rabbi, teacher, and ritual slaughterer, farmed. One poem with the title "near Hirsch a Jewish cemetery" frames the idea of monuments as markers on the landscape:

ann is taking pictures again while I stand in the uncut grass counting the graves: there are forty I think

the Hebrew puzzles me the wind moving the grass over the still houses of the dead

from the road a muffled occasional roar cars passing no one there casts a glance at the stone trees the unliving forest of Hebrew graves in the picture I stand arms outstretched as if waiting for someone

I am

in front of the gates you can see the wind here the grass always bending the stone unmoved ${ }^{14}$ 
Mandel characterizes the monuments as an "unliving forest," as "stone trees," as things caught somewhere between the possibilities of nature and an inanimate world. He's willing, too, to admit his own limitations in deciphering traditional gravestones. The "Hebrew," Mandel writes, "puzzles" him. Do the stones' inscriptions confound his Hebrew comprehension, or is there more to this than mere literacy?

Like the flat marker at Cohen's grave, the old stones in the Hirsch cemetery are bilingual, in Hebrew with a varying amount of English translation. The Star of David on many of the gravestones signals that Cohen's modified star on the otherwise ecumenical upright marker at his grave is not far removed from older, traditional stones. (In the old Jewish cemetery at Lodz, one must walk away from the Poznanski crypt and other grandiose and art moderne monuments to enter an older section of the cemetery, where the Star of David is repeated, along with other traditional motifs: candlesticks for women, book spines for men of letters, a water jug for a Levite, a broken tree to commemorate someone dead before their time). Mandel's grave count is short. One source counts I03 graves, marked and unmarked. ${ }^{15}$ Another counts 50 as of $1970{ }^{16}$ The earliest grave dates from 1888 , the latest from $1970 .{ }^{17}$

The cemetery at Hirsch bears an official bronze plaque, which might be thought of as a variation on the troublemaking one posted by the federal government at the Ottawa Holocaust Monument. The plaque at Hirsch dates from 1976 and was erected, as it is written in all caps, "BY FORMER COLONISTS AND DESCENDANTS IN CO-OPERATION WITH SASKATCHEWAN DEPARTMENT OF TOURISM AND RENEWABLE RESOURCES." The text on the plaque commemorates the full settlement project at Hirsch, rather than the cemetery it stands beside. It acknowledges the "Jewish Immigrants" of "The Baron de Hirsch Jewish Agricultural Colony," their many countries of origin, and their "desire to escape religious persecution and racial discrimination" in the Czarist Empire. But the grave markers themselves provide a more detailed and subtle portrait of these east-European-born prairie Jews. They do this by way of written texts, varied language, and worn facades with modest traditional decoration. The names of the colonists on the graves are too many to list here and run the gamut from Adler to Zelickson. ${ }^{18}$

Mandel's poems are attentive to the way Jews inhabited the landscape. But Out of Place resists telling history in any concrete or didactic way. Mandel's own childhood and the lives of his ancestors appear in fragmentary glimpses, as in the poem "slaughterhouse:": 
after the morning in the slaughterhouse grandfather leading me back to the kitchen the farm unpainted weathered grandmother milking guts of shit for skins and kishke it's not a place for boys she says her face redder than strawberries her hands like cream ${ }^{19}$

The average reader, Jewish and non-Jewish, will struggle to understand the history and cultural memory Mandel conjures. Like the monuments in the Hirsch cemetery, certain motifs and settings in the poems come clear, while others remain coded, puzzling, an outcome that Mandel embraces in his poetic response to the past. It may be that for Mandel this puzzlement is an inevitable, even intrinsic outcome of an excavation of Jewish Canadian markings on the landscape. The monuments at the Hirsch cemetery are only partially readable by the mainstream viewer, and even by a Jew whose access to their ancestors' code-the language and tenor of their cultural outlook-is not assured. Take, for example, Mandel's boyhood memory of culinary and farmyard rituals. Who today would know a kishke if they found one casting its shadow on the landscape? But the landscape itself is kinetic in Mandel's rendering, it retains its own character and acts on its own terms: "you can see / the wind," he writes, "the grass / always bending the stone unmoved."

\section{Coda}

With Cohen's grave site and Mandel's Hirsch poems in mind, we can address a few remaining considerations that arise from the Ottawa Holocaust Monument's relationship to a tradition of Jewish markings on the Canadian landscape. In familiar Libeskind style, the monument's structure is a suite of irregular-looking concrete shapes and structures. At a distance and up close their form is abstract, though from overhead, photographs reveal the shape of a six-pointed star, which commentators relate to "a Jewish star." ${ }^{\text {"I }}$ Libeskind's studio's website puts things distinctly:

The Monument honors the millions of innocent men, women and children who were murdered under the Nazi regime and recognize [sic] those survivors who were able to eventually make Canada their home....

The cast-in-place, exposed concrete Monument is conceived as an experiential environment comprised of six triangular, concrete volumes configured to create the points of a star. The star remains the visual symbol of the Holocaust - a symbol that millions of Jews were forced to wear by the Nazi's [sic] to identify them as Jews, exclude them from humanity and mark them for extermination. $^{22}$ 
This language presents some of the risks and pratfalls of the removed plaque prepared by Heritage Canada. The language of victimhood is introduced neutrally at first, though it proceeds to more particular terms of reference. The assertion that the "star remains the visual symbol of the Holocaust" is debatable; one could more easily argue that "the star remains" a familiar visual symbol associated with Jewish victims of German concentration and death camps. More importantly, Libeskind's website describes the monument's shape not as reminiscent of "a Jewish star" (the kind found on traditional grave markers at Hirsch, and in modified form on Cohen's gravestone) but as a symbol that "Jews were forced to wear by the Nazis," so, a degraded or inverted version, a symbol identifying forms of victimhood and not religious and cultural identity.

A notable set of images completes the monument's distinctive markings on the Ottawa landscape. These are large-scale photographs of Holocaust-related sites by the internationally known Edward Burtynsky, which have been transferred onto concrete in "specially formulated paint and exquisite detail." ${ }^{23}$ Burtynsky, a non-Jew of Ukrainian ancestry, travelled through Poland and central Europe in 20I4. The outcome of his travels was over 250 photographic images of Holocaust-related sites. ${ }^{24}$ Those chosen for the monument include: ceiling adornments from a "prayer room" found in the Terezin Ghetto; a hiding place on the outskirts of the Warsaw Ghetto; an abandoned rail line in the woods near the Treblinka death camp site; and the location of a death march near Mauthausen in Austria. Some of these-the Treblinka woods for instance-are familiar to anyone who attends to iconic Holocaust imagery. This site is among the repeated scenarios in Claude Lanzmann's 1985 film Shoah. One need not have travelled to Poland to know how these woods look to the postwar camera.

The Terezin image is relatively new in the panoply of Holocaust-related imagery, having been discovered in the early I990s as the ghetto memorial site expanded to a new building. ${ }^{25}$ Its decorative motifs, well presented in Burtynsky's photo, include a pairing of varied Stars of David along with stars painted on a ceiling, which resemble stars in the heavens. The Terezín camp is best known, iconically, for its children's art and for the range of musical and theatrical performance undertaken by those incarcerated there, so this is something new, revealing religious life in the ghetto. Burtynsky's Terezín image stands apart from the others at the Ottawa Holocaust Monument, for they are more directly associated with German-engineered sites of mass death. All these images are unlike what one finds on Holocaust memorials erected by Jewish communities in cemeteries or at cultural centres. Jewish hesitation regarding figurative representation might explain this difference, but more importantly, commemoration of Jewish victims by Jews, as with the Vancouver Holocaust monument in the Schara Tzedeck cemetery, is focused on language: on the names of the murdered, often with their ages to reflect the mass murder of children and elderly; on names of killing sites; on home towns and cities where Jews thrived before the 
war; on texts from Psalms and elsewhere in the Bible that bemoan loss, and lead to an accusation, in varying degrees of forcefulness, of the perpetrators. The language of such accusation has tempered over the decades. Early Yiddish versions of such texts were the most direct and unrelenting in tone. The best-known example of this is the dedication to Elie Wiesel's 1956 Yiddish memoir, Un di velt hot geshvign, where Germans are designated as rotskhim - murderers. ${ }^{26}$ One reads these changing Holocaust responses, whether in cemeteries, on monuments, or in epigraphs to books, as a timeline of cultural response and linguistic and religious shifts. They reveal changing postwar Jewish self-identification. The Burtynsky images, though in their way magnificent, are not a direct part of this tradition. Rather, they relate to conceptual art and museum installations that have addressed the Holocaust in recent decades. One might add that as markings on the landscape associated with Holocaust commemoration, they are not Jewish but Canadian, or even international, in their form and language. A visit to the monument on LaBreton Flats is the way to decide where one stands in relation to it, just as Eli Mandel went from Toronto to the cemetery at Hirsch, his ancestral place, to "stand arms outstretched / as if waiting for someone."27

1

My title echoes an artwork on the façade of the Vancouver Art Gallery by the artist Lawrence Weiner, which reads "Placed Upon the Horizon (Casting Shadows)."

\section{2}

Another prominent statue in Montreal, which has been the target of vandals, is that of Queen Victoria in front of the McGill University music school. It dates from 1899.

\section{3}

Simon Schama, Landscape and Memory (Knopf, 1995), 16.

\section{4}

Jesse Toufexis, Email correspondence. June 4, 2020.

\section{5}

Tom Spears, "Here's how the Holocaust Monument came to have a glitch nobody saw coming." Ottawa Citizen Jan. 19, 2019. https://rc-23-2-ottawacitizen.dev.postmedia. digital/news/local-news/heres-how-the-holocaust-monument-came-to-have-a-glitchthat-nobody-saw-coming/wcm/10bc104a6352-4650-9111-a9c02f6c4d31

\section{6}

The former is from signage from the Toronto Narayever synagogue. https://www.narayever.ca/history

The latter is a transliteration of window signage prominent for many years on Toronto's Baldwin Street, near Kensington Market. Amy Grief. blogTO, Oct. 9, 2016. https://www. blogto.com/city/2016/10/kensington_markets_jewish_roots_still_run_deep/

\section{7}

"Ottawa to replace Holocaust plaque after failing to mention Jewish people, anti-semitism." Global News Oct. 5, 2016. https://globalnews. ca/news/3787218/holocaust-plaque-no-mention-jewish-people-anti-semitism-ottawa/ This source includes a screen shot photo of the plaque.

\section{8}

The memorial's development, along with photographs, is described at https://www.vhec. org/stories/holocaust-memorial-schara-tzedeck-cemetary/

\section{9}

The English rendering of the Hebrew dedication placed on the monument might be more directly translated into English as "at the hands of the Nazis." 


\section{0}

I lived in the city when one of its initiators, Renia Perel, went from kitchen table to kitchen table, gathering names and receiving the requisite donations, per name. My grandmother, who lost most of her family in the war, as did her husband's family, agonized over how many of these to include in the memorial's represented names. There was a first list, payment, and then a guilt-ridden addition to the list of some who'd not been included.

\section{1}

An Internet search for "Leonard Cohen grave site" comes up with news coverage, video of visitors at the grave, and many images (including of grave sites related to other Leonard Cohens).

\section{2}

"Nondescript." https://www.merriam-webster.com/dictionary/nondescript

\section{3}

1 Samuel 25:29. The Hebrew letters that show this abbreviation are, read right to life left: $\Omega$

הבצני

\section{4}

Eli Mandel, Out of Place. (Press Porcepic, 1977), 20.

\section{5}

Cyril Kesten, "The Teaching Life." Aug. 1, 2007. http://theteachinglife.blogspot.com/2007/08/ hirsch-cemetery.html

\section{6}

"Saskatchewan Cemeteries Project: Hirsch Community Jewish Cemetery." https://sites. rootsweb.com/ cansacem/hirsch.html

\section{7}

"Saskatchewan Cemeteries Project: Hirsch Community Jewish Cemetery." https://sites. rootsweb.com/ cansacem/hirsch.html

\section{8}

Saskatchewan Cemeteries Project: Hirsch." https://sites.rootsweb.com/ cansacem/hirsch. html

19

Mandel, 22.

\section{0}

Mandel, 20.

\section{1}

Jill Stoner. "A Monumental Statement: National Holocaust Monument, Ottawa." Canadian Architect. Mar. 8, 2019. https://www.canadianarchitect.com/a-monumental-statement/

\section{2}

Studio Libeskind. "National Holocaust Monument." https://libeskind.com/work/national-holocaust-monument/

\section{3}

Stoner, https://www.canadianarchitect. com/a-monumental-statement/

\section{4}

https://www.edwardburtynsky.com/projects/ books/chai

\section{5}

Terezín Memorial. https://www.pamatnik-terezin.cz/prayer-room-from-the-time-ofthe-terezin-ghetto-and-replica-of-attic This site provides remarkable photographs of the source for Burtynsky's photograph.

\section{6}

Elie Wiesel, Un di velt hot geshvign. (Tsentral-Farband fun Poylishe Yidn in Argentine, 1956), n.p.

27

Mandel, 20. 